\title{
Villain Figure's Ambivalence in the Comic Gundala: Destiny
}

\author{
Irish Hening*, Suma Riella Rusdiarti \\ Literature Master's Program, Faculty of Humanities, Universitas Indonesia \\ *irishhening27@gmail.com, sumariella@ui.ac.id
}

DOI: 10.20884/1.jli.2020.11.2.3451

\begin{abstract}
Article History:
First Received:

ABSTRACT

$01 / 11 / 2020$

In the comics with superhero genre, the reader will see a villain figure as the

Final Revision: opponent of superhero. In September 2019, Bumilangit in collaboration with Gramedia Pustaka published the comic Gundala: Destiny as the

$10 / 12 / 2020$ complementary media adaptation to the movie Gundala: This Country Needs Patriots which was also published in the same year. This comic presents the

Available online: figure of Sancaka against Pengkor. Unlike the movie, the main point of

$29 / 12 / 2020$ narration in the comic is from the perspective of Pengkor as the villain. The comic's narrative shows the story of Pengkor's childhood until he became a mafia who is feared and respected by many people. With his power, Pengkor has both socially or politically dominance. His power also works with his 10 adopted children as the victims of his subordination. However, Pengkor's actions to create power over his children were carried out without coercion and repression. In this way, his adopted children obeyed and glorified Pengkor with the nickname 'Father'. By using the structural theory of Tzvetan Todorov and the hegemony of power from Antonio Gramsci, this study aims to dismantle the ambivalent power attitude of Pengkor as the villain figure in the comic Gundala: Destiny.
\end{abstract}

Keywords: ambivalence; printed comic; domination; hegemony; villain

\section{INTRODUCTION}

The genre superheroes in American comics has captivated society in the contemporary era. These comics later became a commodity of popular culture. Reynolds (1992) stated that the emergence of the superhero genre was initiated by two things, namely the presence of Superman in 1938 as a sign of the Golden Age in American comics and then the ideological influence that triggered the beginning of World War II in Europe. Superman is the trigger for the emergence of superhero narratives as a new genre in America. In Indonesian comics, the superhero genre started to rise after the Indonesian independence. Imanda (2014) stated that the influence of Western comic strips was so strong and already influenced so many Indonesian local comics, especially in its narration and the graphic styles. Zpalanzani (2006) also adds that characters such as Gundala, 
Sri Asih, Puteri Bintang, and also Garuda Putih clearly show the influence of American comic book characters which already existed.

The most recognized Indonesian comics with genre superheroes was Hasmi’s Gundala Putra Petir which was published in 1969. The success of the comic leads the story of Gundala to many of adaptation products. As the result, in 2019, this comic was adapted into movie with a new narrative story entitled Gundala: This Country Needs Patriots. After its movie adaptation, Bumilangit collaborated with Gramedia Pustaka to publish the printed comic Gundala: Destiny whose narrative was created by Oyasujiwo and the drawings were made by Ardian Syaf, a comic artist from Indonesia who has also ever worked for DC Comics and Marvel. Printed comic Gundala: Destiny is an adaptation of the movie which was released in the same year. The text shows the reader to see Sancaka as a Gundala who will fight the injustice which caused by the society and the villain, Pengkor.

Gundala's printed comic presents another alternative to understanding the world of Gundala's stories. Readers are given the opportunity to understand the story line from the point of view of Pengkor as the villain. Thus, Pengkor acts as a narrator and focalist in the text of Gundala: Destiny. Pengkor's life from childhood to become a villain is presented very clearly in the comic and more detailed than the movie. Pengkor is a mafia who is respected and feared in Jakarta. He also has a strong dominance in society and government. In carrying out these crimes, Pengkor is assisted by the ten of his adopted children whom he foster from childhood to adulthood, namely Kamal Atmaja (the whisper), Tanto Ginanjar (the forge), Jack Mandagi (the chef), Sam Buadi (the sculptor), Mutiara Jenar (the model), Cantika (the nurse), Adi Sulaiman (the composer), Desti Nikita (the student), Swara Batin (the dancer) and Kanigara (the painter). However, the power relationship between Pengkor and his 10 children doesn't show domination and repression. Pengkor exercises his power by forming an ideology about the family based on the legend of the 12 guards. The bond between the Pengkor and the children is based on the children's obedience to all the Pengkor's orders.

The relationship between Pengkor and his children and Pengkor's power over them can be linked to Gramsci's hegemony of power. Pengkor as a respected figure shows his position as the owner of power. Even so, Pengkor exercises his power without coercion and his adopted children consciously carried out all his orders. Pengkor's hegemony tends to lead to the 'ideology of a family' in the comic Gundala: Destiny. However, Hikmah in her thesis (2009) states that comics are not only a means of spreading hegemony, but also a tool to fight against that hegemony. In the Gundala comic's text at the end of the story, there are two Pengkor children resisting the Pengkor's control of power. Based on previous research, the author has not found any research on the Pengkor 
figure in the comic Gundala: Destiny. Than based on this research, the hegemony of Pengkor is a power based on the existence of an ideology of family. However, in the comic, Pengkor's character has an ambivalent attitude of power, namely dominating and non-dominating power. Therefore, this research is expected to uncover the ambivalent attitude of Pengkor's power which is presented through the printed comic media Gundala: Destiny.

To dissect the comic text of Gundala: Destiny, this research will use the structural theory of Tzvetan Todorov (1985) which can be used to describe the narrative elements in the text by paying attention to three main aspects. The first is the syntax aspect related to the storyline to describe the sequence and causal relationships in the text. Then proceed with semantic aspects related to characterization and setting of place / time in the story to determine its meaning. After that, the writer also looks at the verbal aspect of the mode category to see the stage of presence of events in the text which related to time and the point of view of the storyteller which will be directly related to the ambivalence of Pengkor's power practice.

Then to examine the practice of power in the text, this research will also use the concept of hegemony of power from Antonio Gramsci (1992). Hegemony is centered as a cultural and ideological means in which dominant groups in society who want to preserve their dominance by securing subordinate groups without coercion. This political superiority must be maintained continuously. Gramsci also views that the power structures between social classes in society are intertwined not only through forms of coercion and repression, but through moral and intellectual leadership. This is different from the concept of domination, which is generally power by coercion and repression, which creates fear for subordinated people.

\section{METHOD}

In this study, the authors use a qualitative approach. The authors collect data from printed and online sources, such as books, journals and trusted websites. Through analysis-related sources, the author is able to analyze the structure of the text using Tzvetan Todorov's structural theory and uncover the ambivalent attitude of Pengkor in the text based on the hegemony concept from Antonio Gramsci. Thus, comic text is able to present the ambivalence of Pengkor's power as a villain in comic texts. 


\section{RESULT AND DISCUSSIONS}

\section{The Structure of Comic : Syntax Aspects}

Printed Comic Gundala: Destiny consists of 12 chapters with titles based on the nicknames from Pengkor and his ten adopted children also the main character Sancaka. Based on the analysis, this comic has 37 sequences. In details will be seen that there are 26 sequences telling the life of the little Pengkor until his death, seven sequences about the little Pengkor's past and 17 sequences regarding the relationship between Pengkor and his adopted children. But apart from Pengkor's focalization, there are also nine appearances of sequence which tell the life of Sancaka from childhood to adulthood and he fights against Pengkor, the two other sequences tell about other stories outside of Sancaka and Pengkor. It can be seen from the sequence categorization that the appearance of the Pengkor character and his relationship with his adopted children dominate the stories in the comics. Chronologically, the story began with the death of Sancaka and Pengkor's father, which is then followed by their very difficult childhood to survive in Bogor and Jakarta. Then Pengkor tried to build a new family with his children until finally he did battle with Sancaka and ended with the death. From the chronology, it can be seen that the storyline is a mixed plot with a forward and backward plot in the form of flashbacks (past memories). The motives that are presented in the text include sadness, hatred, violence, murder, and longing.

Of the 37 existing sequences, there are six main functions, namely as follows:

\section{The beginning of Pengkor's suffering: the murder of Pengkor's father}

This sequence shows the beginning of Pengkor's suffering which later leads him to become a villain. The laborers confronted demonstrations to their families as the owners. In the comic panel, it appeared that Pengkor's father was hanged and Pengkor's family house was burned which causing Pengkor's body to partially burnt. Through this incident, it was seen that the social and economic disparities in the community were the initial causes of suffering for Pengkor.

\section{Pengkor's suffering lives on the streets}

After a terrible incident at his family's plantation, Pengkor was an orphan with burns on his body. Through the depiction in the comic panel, it can be seen that neither person nor family wanted to take care of Pengkor until he finally entered an orphanage where he became a busker and drug courier. The rough treatment of the orphanage workers towards the orphanage children triggered a rebellion within Pengkor and the orphanage children. Within this sequence, the Pengkor's ability to influence and control others begins to take shape.

\section{Pengkor's hatred against injustice in society}


After being released from the orphanage, Pengkor and the children of the orphanage decided to live on the streets. However, life on the streets was also very harsh and they often got hungry. From this incident, Pengkor was disappointed and angry at people who did not value and waste everything in this life. Pengkor's hatred of injustice has made him as a criminal who hunted the rich man.

\section{Pengkor builds a new family}

Pengkor no longer has a biological family, so he formed a new family with abandoned children. When he grew up, he built a new family based on the legend of the 12 guards. Sancaka is one of the last members who Pengkor would recruit. This family concept is one of the Pengkor ways to exercise his hegemony towards his ten adopted children.

\section{The fight of Pengkor and his adopted children with Sancaka}

In this sequence, Pengkor and his ten adopted children found Sancaka. They then fought. Sancaka realized that so far Pengkor has tried to get him to join the Pengkor family, but Sancaka refused. In this incident, Kanigara, one of the Pengkor children who was able to see the future, also realized an oddity.

\section{Defeated Villain}

Kanigara knows the rottenness of Pengkor that has arranged all the misfortune events for him and other adopted children. Pengkor did it in the purpose so that they want to become his adopted children and obey all his orders. At the end of the story, Pengkor and his seven children were lost to Sancaka. Meanwhile, Kamal, Kanigara and Desti left the battle.

\section{The Structure of Comic: Semantic Aspects}

In this section, the discussion will focus on important figures, time and place settings that are presented in the comic text. Analysis of the characters and characterizations will be carried out in terms of appearance, character and attitude and stories of their past. This character analysis will help to further interpretation of the text. 


\section{Pengkor}

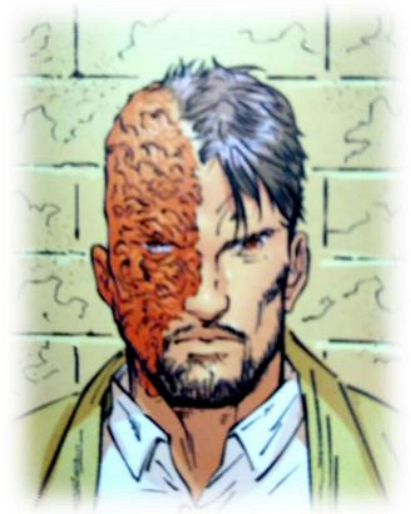

Sancaka
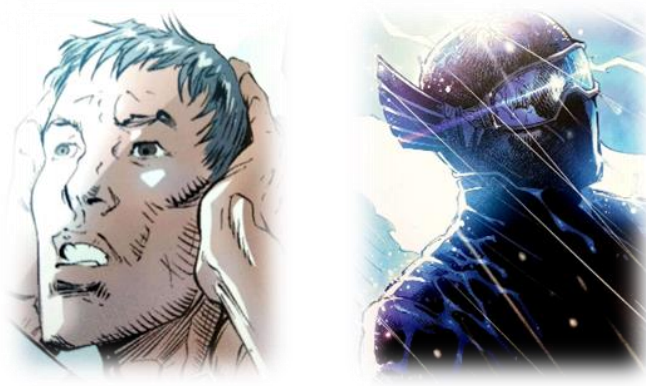

Kamal Atmaja

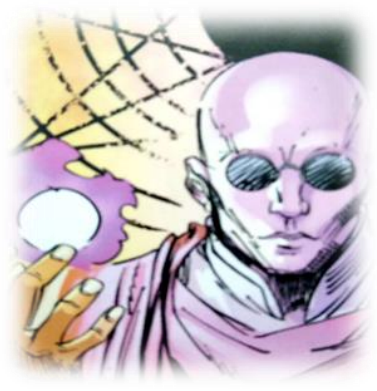

Tanto Ginanjar

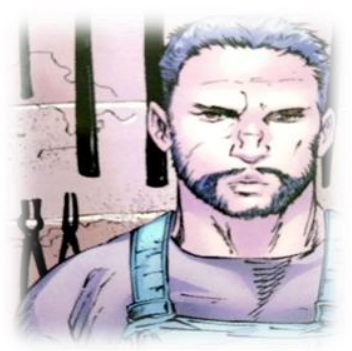

A wealthy mafia who is feared in Jakarta. He got burns all over the right side of his body as a result of the terrible events in his childhood. The rebellion of the plantation laborers against his family as the owner is the beginning of a hard life for Pengkor. After that incident, the harshness of life as an orphanage and street child shaped Pengkor's attitude and outlook towards the world until he eventually became a mafia boss.

Sancaka is the son of a factory worker who also lost both of his parents than he became street children. As an adult, he realized his power which able to extract and control lightning from his body and becomes the enemy of Pengkor.

$\mathrm{He}$ is one of Pengkor's adopted children who was called as the whisper. He is a male figure who looks like a monk and always wears black glasses and a scarf around his neck. He has the magical ability to enter other people's minds and hypnotize others with his whisper with the word sare.

Tanto works as a blacksmith and he has a nickname "the smith". When he was a child, Pengkor inherited a knife to him from his childhood's friend when he started a rebellion in the orphanage. 
Jack Mandagi

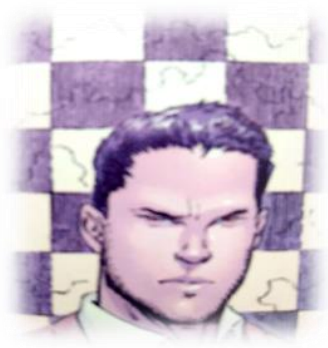

Sam Buadi

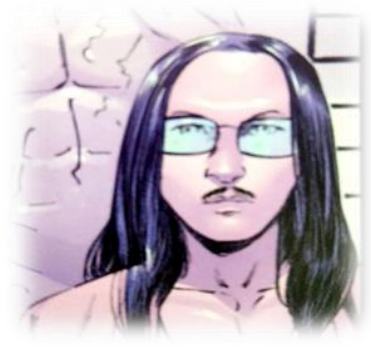

Mutiara Jenar

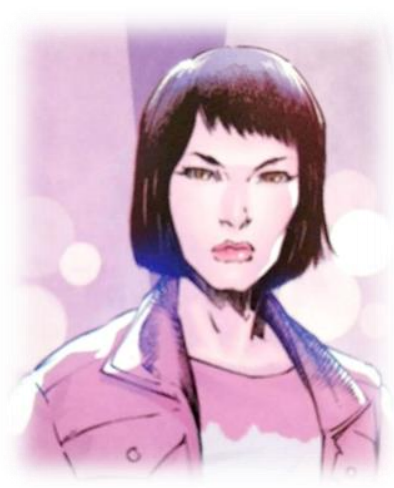

Jack lost his mother in a bus accident when he was a child. After that, he lived with his father who treated him badly and often tortured him. He is an culinary expert, so his nickname "the chef".

Sam was found by Pengkor under the rubble of a building and cooped up there alone for two days. His father left him there and Pengkor adopted him as his son who was later given the nickname "the sculptor".

The beautiful Mutiara Jenar has nicknamed "the model". She was abandoned by his parents as a baby and later adopted by a family. When she was older, her adoptive mother gave birth to twins. Her younger siblings didn't want to admit her as a sister because she was just an adopted child. Then, Pengkor invited her to join Pengkor in forming a new family. However, then she married and soon their relationship foundered. After that she looked for his biological parents and found her father who did not even recognize that she was his daughter, so at the end she returned to the Pengkor family.

Cantika

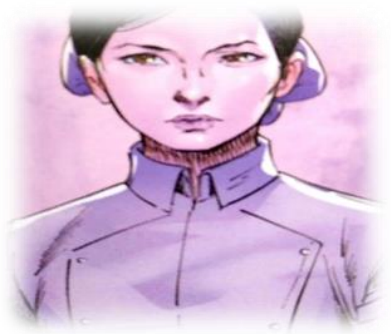

Cantika was given the nickname as "the nurse". Cantika's parents separated when she was young and she was taken care of by her father. When she was a teenager, her father died and her mother's new family refused to take care of her. Pengkor took this opportunity to invite her to join the Pengkor's family and turn her into a deadly murder weapon. 
Adi Sulaiman

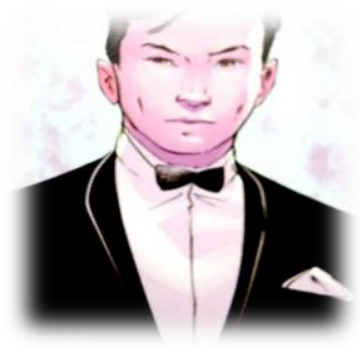

Desti Nikita

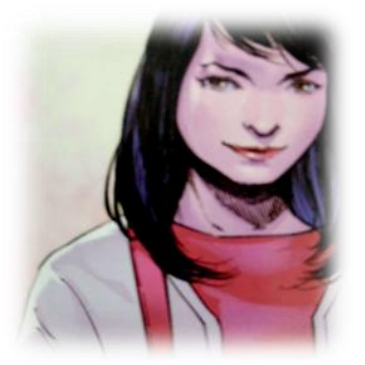

Swara Batin

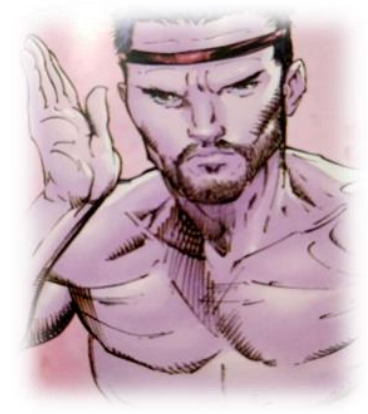

Kanigara

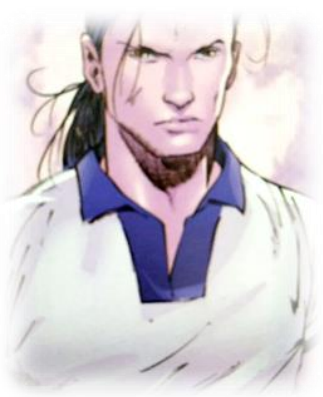

One of Pengkor's children who was able to hypnotize people with his violin composition until he got the nickname "the composer". Through his ability, Adi moved people to burn the market. He is described as a person who is calm and very obedient to Pengkor. He carried out Pengkor's order to fight with Sancaka and let himself be killed by being hit by a truck according to Pengkor's order $\mathrm{d}$ interests.

When she was still little, he was a scavenger who lived with his father. However, the father died being killed by some people. Pengkor then adopted her as a child and he likes her intellectual abilities. Desti got the nickname 'the student' because she always asks so many things and likes to learn various things.

He was one of Pengkor's strongest adopted children and was nicknamed "the dancer". He is pictured always wearing a mask during the fight.

Kanigara earned the nickname "the painter" because of his exquisite painting skills. In addition, he can enter into other people's minds when he touches that person's body and is able to transmit what he sees to others. At the end of the story, Kanigara finds out that all this time Pengkor has been managing all the missfortune events experienced by Pengkor's adopted children.

Through the characterizations which are described above, it can be seen that Pengkor controls the lives of his ten adopted children and invited them to join his new family in a very 
subtle way. Pengkor's adopted children consciously obeyed all Pengkor orders even though they were only being used by Pengkor. By taking advantage of the situation, Pengkor was able to order his adopted children to strengthen his dominance in society.

Apart from the characterizations, the setting of place and time also has a certain meaning. In the comic text Gundala, the location of Pengkor's childhood incident was on the Pengkor family's plantation in the Bogor area in 1975 and was followed by his move to the city of Jakarta, while Sancaka's childhood was in Jakarta in 1999. Despite being 24 years apart and in the different city. Both regional conditions have the same regional problems, namely the existence of high social disparities in the society. This triggered conflict in their childhood which led to the death of their father. In 2015, the situation was grim and crime was still happening. However, there is a difference between the Pengkor character, who in his childhood was a victim of crime and human greed. Adult Pengkor transforms from a suffering person to a criminal who is respected and feared by society.

\section{Pengkor's Power Practices}

Power can be divided into two, namely domination and hegemony. In a power that applies domination, subordinated people will feel depressed and afraid to oppose the superior. Meanwhile, when a ruler applies hegemony, the subordinated do not feel like they are being repressed even though they are actually being controlled. In the text Gundala: Destiny, the figure of Pengkor as an enemy (villain) has power in the society and its surrounding. In the comic panel, we can see that Pengkor and his subordinates are negotiating with the leadership of the government council.

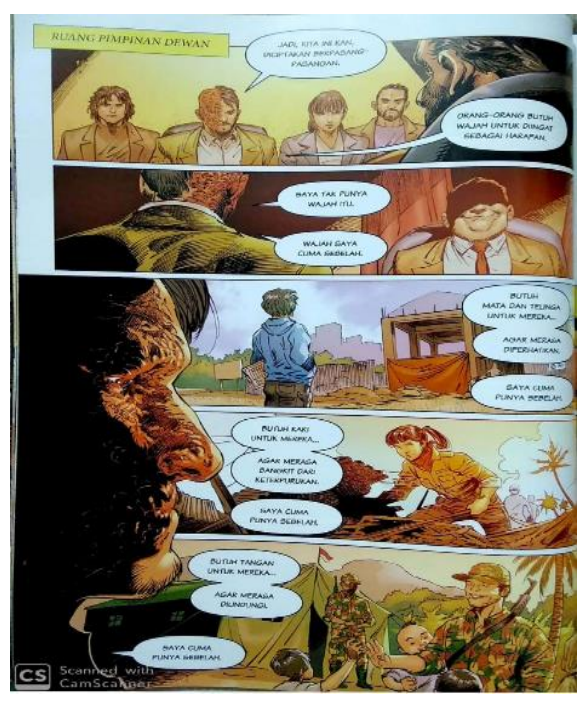

Picture 1.1. Pengkor's Negotiation Through his perspective, he expressed his desire to work with the leader of council. He explained to the council about his shortcomings plan so that he could not go forward in public to attract the hearts of the public. He explained the people's desire to be heard, protected, and this hope could only be realized by the leader who is normal physically. He will help the leader of the council behind the scenes to do all actions to attract the hearts of the public. Here, Pengkor tries to build a relationship with the party who also has the highest power in society. 


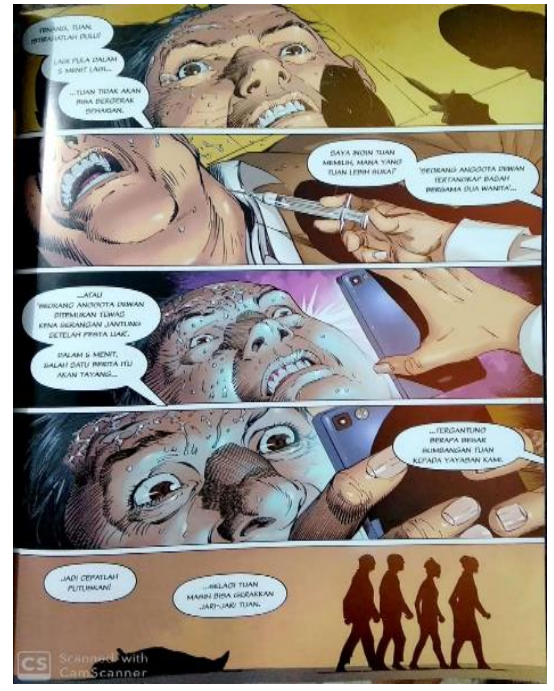

His negotiation with the leadership of the council is one of the Pengkor's efforts to build his power among government people so that he gets a high position in society. In exercising his power, Pengkor does not hesitate to carry out violence against people who against and interfere his plans. In the picture in the left side, Pengkor ordered Cantika to come to the house of the council leader who was previously invited to work with him. In this context, Pengkor has gained power and dominance in government people and society, so he no longer needs the leadership of the corrupt council.

Picture 1.2. the Leader of Council's Murder

In the panel, readers can see that the leader of council was afraid and depressed by the presence of Cantika and other Pengkor subordinates. This indicates how the domination of the Pengkor power works. Council leaders who hold the highest positions in the government are even afraid to Pengkor. It happens so logically because Pengkor uses violence and threats to perpetuate his power. Even after the council leader obeyed the order to transfer a certain amount of money to him, in the end the leader was still killed by Cantika on the order from Pengkor.

However, from this incident, the reader can also see the position of Pengkor's powers. Cantika's compliance to carry out order from Pengkor also indicates a power value. Cantika is one of Pengkor's adopted children who is used as a murder weapon by Pengkor. After the murder of the council leader by Cantika, Pengkor said "Nice, Cantika. You can always be counted on. We have logistical guarantees to move optimally. Thanks. Thank you, beautiful." From the utterances uttered by Pengkor, it can be seen that he gave Cantika high appreciation for the crime. The utterance that was uttered by Pengkor to Cantika was actually just an attempt to perpetuate his domination of power over Cantika to remain her as a murder weapon for the interests of Pengkor's power.

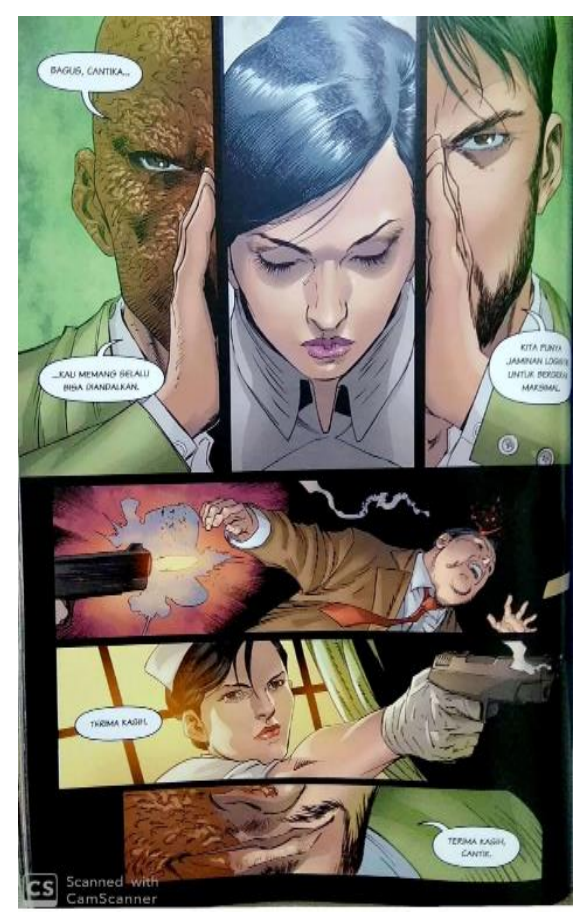

Picture 1.3. Pengkor and Cantika

In contrast to the dominance of the Pengkor power in the repressive and violent acts over government, the domination of Pengkor's power over his ten adopted children does not indicate repression. Every expression of appreciation given by Pengkor is an effort to maintain his power 
over them. This is in the same line with Gramsci's hegemony principle, that in order to maintain its power, the rulers will continue to lead and maintain it continuously. Pengkor gathered ten adopted children who had various family problems. Through their sufferings, Pengkor came into their lives and invited them to join together with Pengkor to form a new family. Therefore, Pengkor is considered a great figure through the nick name 'Bapak (Father)' as Kamal Atmaja said: "Like when you found me ... found 'us'. You said you saw us, long before meeting us." The title 'Bapak (Father)' strengthens the position of Pengkor's power over his adopted children. Pengkor's position as a father is considered as a protector and savior for his adopted children. By using the concept of family ideology over his adopted children, Pengkor's symbolic violence works. However, at the end of the story, Kanigara, who is also one of Pengkor's adopted children, knows that Pengkor is the mastermind behind all the misfortunes and suffering of his adopted children. Pengkor deliberately creates tragedy in their lives so that they feel alone and want to join Pengkor in forming a new family. At this time, Kanigara and Desti chose not to help Pengkor against Sancaka. This indicates that they are fighting the hegemony that has been internalized within them as the adopted children of Pengkor.

\section{CONCLUSION}

Printed comic Gundala: Destiny presents a depiction of life in Bogor and Jakarta which is harsh and has led to many crimes. Through this comic, readers can understand the story line from the point of view of Pengkor who is the narrator and focalist as a villain. In the text, the power of Pengkor is ambivalent. On the one hand, it exercised violent domination and repression, especially against the government. On the other hand, however, he strengthens his power in a subtle way and without repression. This position of power works within his ten adopted children. He uses the ideological concept of family to his children. This also shows the position of Pengkor who is also an orphan and he also has a longing for family existence. However at the end, this family concept was only a tool for the Pengkor to perpetuate his power. Hopefully this research could give a new contribution for literature research and could be useful for the further research regarding the theme of superheroes and villains.

\section{ACKNOWLEDGEMENTS}

I would like to express my gratitude to DRPM Universitas Indonesia, Depok, West Java which has given the opportunity to me to conduct this research with the support from Research Grant PUTI 
(Publikasi Terindeks Internasional) for Social-Humanities. My grateful also dedicated for Dr. Suma Riella Rusdiarti as the co-writer who has also given alot of suggestion for the perfection in this article. The last, this research is dedicated to Indonesian research in the field of transmedia studies which still growing.

\section{REFERENCES}

Browne, R. B. (2006). “Popular Culture: Notes Toward Definiton.” Harold E Hinds, Marilyn Ferris Motz, Angela M. S. Nelson. Popular Culture Theory and Methodology: A Basic Introduction. Wisconsin: The University of Wisconsin Press.

Gramsci, A. (1992). Buttigieg, Joseph A, ed. Prison Notebooks. New York City: Columbia University Press.

Heit, J. (2011). “Introduction.” Vader, Voldemort and Other Villains. Ed. Jamey Heit. Jefferson, NC: McFarland \& Co.

Hikmah, N. (2009). Konstruksi Perlawanan terhadap Hegemoni Iran (Analisis Semiotik terhadap Novel Grafis Persepolis: The Story of a Childhood Karya Marjane Satrapi). Depok: Universitas Indonesia.

Imanda, T. (2014). Komik Indonesia itu Maju: Tantangan Komikus Underground Indonesia. Depok: Universitas Indonesia.

Khoiri, A. (2017). Ardian Syaf, Komikus Tulungagung Pemikat DC Comics dan Marvel. Diakses melalui https://www.cnnindonesia.com/hiburan/20170410114154-241-206251/ardian-syafkomikus-tulungagung-pemikat-dc-comics-dan-marvel?

Oyasujiwo dan Syaf, A. (2019). The Official Movie Adaptation: Gundala. Jakarta: Gramedia Pustaka Utama.

Reynolds, R. (1992). Superheroes: A Modern Mythology. Jackson: University Press of Mississippi.

Todorov, T. (1985). Tata Sastra (diterjemahkan oleh Okke K.S. Dzaimar, Apsanti Djokosudjanto dan Talha Bachmid). Jakarta: Djambatan.

Zpalanzani A., Ahmad, H., \& Maulana, B. (2006). Histeria Komikita: Membedah Komikita Masa Lalu, Sekarang dan Masa Depan. Jakarta: Elex Media Komputindo. 